\title{
“TAKING ON THE TECHNICALITIES” OF INTERNATIONAL LAW - PRACTICE, DESCRIPTION, CRITIQUE: A RESPONSE TO FLEUR JOHNS
}

\author{
Gavin Sullivan*
}

By laboring underneath the radar of formal law, using a diverse array of conceptual tools and working from material disregarded by mainstream legal scholarship, Fleur Johns' research has consistently opened up novel ways of grappling with international legal problems. The article at the focal point of this symposium continues to push the envelope of international legal studies. It sheds light on how the rise of Big Data and algorithmic decisionmaking is transforming international authority. It also speaks to the increasing deformalization of international law. Examining the mundane practices of global governance may sound unrevealing to some. But Johns shows how this approach can yield important insights into international law's operations and effects.

Rather than focusing on the "sensational jurisprudence" of this text, my intervention highlights two important analytical moves that Johns makes: studying international law through its technical practices and deploying a descriptive method to capture and critique its movements. ${ }^{1}$ These moves sound straightforward, yet they rarely feature in international legal scholarship. By situating Johns' approach within broader debates unfolding in the social sciences and sociolegal studies, this essay aims to help bridge the theoretical gap. ${ }^{2}$ I discuss the key analytical advantages of Johns' approach and also set out some questions and tensions that arose in my reading of the text. In short, this article is refreshing, critical, and generative. It maps how automation is changing international organizations and global governance and provokes us to ask how power might be redistributed in the process.

\section{Practices}

The first key move that this article makes is to analyze international law as an effect of material practices. Rather than offering a doctrinal reading of recent changes to nuclear nonproliferation or international refugee law, Johns zooms in on the everyday practices and techniques through which "international institutions and other agents of international law take in or record seemingly unprocessed data about the world and its human and nonhuman inhabitants." 3 Such a practice-based approach remains relatively novel in the domain of international law, where most accounts still privilege positive norms, formal binding powers and "solid authority" models as the cause and effect of legal change. ${ }^{4}$ Yet it resonates with recent shifts in social science scholarship aimed at showing how objects, legal forms, relations, and institutions are enacted through practice.

* Lecturer, Kent Law School, University of Kent (UK) and Solicitor, Senior Courts of England and Wales.

${ }^{1}$ Law and the Senses: Sensational Jurisprudence (Lionel Bently \& Leo Flynn eds., 1996).

2 The title of this essay is drawn from an article that Johns draws from and builds on in this text. See Annelise Riles, New Agenda for the Cultural Study of Law: Taking on the Technicalities, 53 BufF. L. Rev. 973 (2005).

${ }^{3}$ Fleur Johns, Data, Detection, and the Redistribution of the Sensible in International Law, 111 AJIL 61 (2017).

${ }^{4}$ Nico Krisch, Authority, Solid and Liquid, in Postnational Governance, in Authority in Transnational Legal Theory: Theorising Across Disciplines 25 (Roger Cotterrell \& Maksymilian Del Mar eds., 2016).

\footnotetext{
The American Society of International Law and Gavin Sullivan (C) 2017. This is an Open Access article, distributed under the terms of the Creative Commons Attribution licence (http://creativecommons.org/licenses/by/4.0/), which permits unrestricted re-use, distribution, and reproduction in any medium, provided the original work is properly cited.
} 
Science and Technology Studies (STS), for example, has long moved outside of the laboratory to examine how sociotechnical chains of material-semiotic relations and agents are aligned and held together in practice to produce forms of organization and knowledge. In Actor-Network Theory (ANT), "realities, objects, subjects, materials, and meanings ... are all explored as an effect of the relations that are assembling and doing them." ${ }^{5}$ Constructivist international relations (IR) scholars have also foregrounded practice as the smallest unit of analysis. By focusing on how tacit knowledges, bodily routines and epistemic practices embedded in technical artifacts are stabilized into norms and institutions, the "practice turn" in IR has allowed more relational approaches to world politics to emerge. ${ }^{6}$ Legal anthropologists like Annelise Riles have drawn on STS scholarship to show how prosaic legal techniques and marginal market practices—what she calls "collateral knowledge" — enable "thin but nevertheless robust sociotechnical relations among individuals and machines in different institutions, cities and countries" that make global financial governance possible. ${ }^{7}$ For Riles—-to whom Johns is clearly indebted in this articlelegal governance "is ultimately not so much a matter of grand designs as it is a set of lived practices and techniques." 8 Understanding legal change requires "taking on the technicalities" of law to examine how legal knowledges are formed through practice. ${ }^{9}$

"Taking on the technicalities" is precisely the broader aim of Johns' article. By analyzing how monitoring practices of nuclear nonproliferation and refugee registration are changing with the rise of Big Data analytics and biometric identity management systems, Johns offers insights into how the authority of international organizations is assembled and sustained in the present. Instead of relying on a professional elite of nuclear weapons inspectors as in the past, current International Atomic Energy Agency (IAEA) verification practices, for example, enroll an array of different actors - many of whom remain publicly unknown - into this domain of international legal work. The manual economy of document evaluation, long central to the expertise of nuclear inspectors, is being supplanted by the turn toward automation and public fascination with "the latest kit." ${ }^{10}$ Whilst such changes may be irrelevant for most international lawyers, for Johns they are potentially profound. They make global governance possible without the need for a legal subject and effect a "redistribution of the power to establish and contest the condition of the world," embedding "new modes of enfranchisement and disenfranchisement." 11 Yet because the inner workings of how algorithms assemble relations is digitally opaque, Johns argues that we currently lack the politicolegal vocabulary for negotiating what automation puts at stake.

Johns distinguishes her approach to these issues from the concerns of mainstream scholarship. First, in Johns' account existing debates about privacy and due process miss the point. By focusing on relations between individuals and public/private actors, they obscure the broader "distributional implications of technological developments for international legal order." 12 Second, the literature on expertise and international law is said to be of limited relevance here because it focuses on the knowledge practices and jurisdictional struggles of experts. ${ }^{13}$

\footnotetext{
${ }^{5}$ John Law, Collateral Realities, in The Politics of Knowledge 157 (Fernando Dominguez Rubio \& Patrick Baert eds., 2012).

6 The Practice Turn in Contemporary Theory (Theodore R. Schatzki et al. eds., 2001).

7 Annelise Riles, Collateral Knowledge: Legal Reasoning in the Global Financial Markets 230 (2011).

${ }^{8} I d$. at 246.

${ }^{9}$ Id. at 64-70; Riles, supra note 2. See also, Mariana Valverde, Jurisdiction and Scale: Legal "Technicalities" as Resources for Theory", 18 Soc. \& LegAL STUD. 139 (2009).

${ }^{10}$ Johns, supra note 3, at 90. See also, Documents: Artifacts of Modern Knowledge (Annelise Riles ed., 2006).

${ }^{11}$ Johns, supra note 3 , at 100, 101.

12 Fleur Johns, Global Governance Through the Pairing of List and Algorithm, 34(1) Env'T \& Plan. D: Soc'y \& SpaCE 126, 130 (2016); Johns, supra note 3 , at 101 .

${ }^{13}$ Martti Koskenniemi, The Fate of Public International Law: Between Technique and Politics, 70 Mod. L. Rev. 1 (2007); David Kennedy, A World of Struggle: How Power, Law and Expertise Shape Global Political Economy (2016).
} 
Johns shows us that expert knowledge is not essential to machine learning processes and that algorithmic governance is often carried out by low-level officials who "operate the machines" and make "little to no claim to expertise at all." ${ }^{14}$ For Johns, automation is revising international law's very ability to "conduct juridical relationships on the global plane" in ways that are passing unnoticed by legal scholarship. ${ }^{15}$

One of the advantages of practice-based approaches like Actor-Network Theory (ANT) and governmentality scholarship is that they provide a means for "following the actors" and tracing how "multiple and very diverse processes ... gradually coagulate and form an effect." 16 They help show how heterogeneous practices and techniques are woven together in ways that produce new relations, actors, and forms of power. It is this constitutive movement from the micro to the macrowhat ANT theorists call a "translation" - that gets lost in "meso-level" descriptions of change. ${ }^{17}$ Johns' article provides an evocative glimpse of how algorithms stand to transform international law and authority. But the broader political claims made about global inequalities are more difficult to sustain through brief "snapshots" advanced in an avowedly speculative mode. ${ }^{18} \mathrm{I}$ also found myself wanting to push the changes described by Johns further to know more about what they $d o-$ not just in terms of international law's earlier sensory economy, but also in relation to the assemblage of practices, new networks, and forms of power they enable.

The rapid uptake of UNHCR biometric registration, for example, is being driven not only by concerns of efficiency and "recycling," but also by the need for humanitarian actors to avoid indirectly financing terrorism by ensuring assistance is only provided to "genuine" refugees. ${ }^{19}$ This requires rendering refugee registration data interoperable with other biometric databases to identify potential persons of interest. Pakistan and Afghanistan maintain some of the largest national biometric databases in the world. So what happens to the refugee registration data collected by UNHCR? With whom is that data shared? When the information moves from one database to another, what actors and institutions does it bring together? In short, what kinds of novel practices and relations is the securitization of refugee registration enabled by biometrics facilitating? It is suggested that the UNHCR's shift towards biometrics signals a move away from population data toward more individualized registration. ${ }^{20}$ Yet donors to humanitarian assistance programs have emphasized the important role that biometrics play in delivering "more accurate population data." ${ }^{21}$ How are these conflicting rationales smoothed out in practice? How is individual biometric data collected by field officials circulated and transformed into population data for international donors? What new governance is this enabling? And what are the implications of these movements for the normative purchase of international law?

Johns' critique aims to allow us to "experience the international legal field afresh and ... acquire a new 'feel' for the political possibilities available within it" and my questions suggest that the article indeed does that. ${ }^{22}$ Instead of only seeing the world structured through powerful institutions and agency contained in the hands of powerful

${ }^{14}$ Johns, supra note 3 , at 64 .

${ }^{15} \mathrm{Id}$. at 59 .

${ }^{16}$ Bruno Latour, Science in Action: How to Follow Scientists and Engineers Through Society (1987); Michel Foucault, Security, Territory, Population: Lectures at the Collège de France 1977-78 248 (2007).

${ }^{17}$ Johns, supra note 3, at 66; Michel Callon \& Bruno Latour, Unscrewing the Big Leviathan: How Actors Macro-Structure Reality and How Sociologists Help Them to Do So, in Advances in Social Theory and Methodology: Toward an Integration of Micro and MacroSociologies 277 (Aaron V. Cicourel \& Karin Knorr-Cetina eds., 1981).

18 Johns, supra note 3 , at 59 .

${ }^{19}$ Katja Lindskov Jacobsen, UNHCR, Accountability and Refugee Biometrics, in UNHCR AND tHe StRUgGLE FOR AcCountabilitY: Technology, Law and Results-Based Management 159 (Kristin Bergtora Sandvik \& Katja Lindskov Jacobsen eds., 2016).

${ }^{20}$ Johns, supra note 3 , at 96.

${ }^{21}$ Jacobsen, supra note 19, at 164.

22 Fleur Johns, Non-Legality in International Law: Unruly LaW 27 (2013). 
actors, here things are ontologically reversed. Institutional formations and agency in global governance are recast as effects of practices and this is one of the text's core strengths. Yet a "deep[er] empirical dive into the details" and more forensic mapping of what these technicalities do would strengthen the article's core claims about the redistribution of international law's power and "associated routes for thinking and action" that these changes potentially open up. ${ }^{23}$

\section{Description}

The second key move of Johns' article lies in its attention to method in international law. Reflecting on his own legal education, Martti Koskenniemi has remarked: "Either 'method' equalled discussion about formal sources or it referred simply to techniques of finding the collections of documents from which authoritative statements about the law could be found." 24 Methodology, in other words, is shorthand for the techniques used by lawyers to "find the law." Even the recent "empirical turn" in international legal scholarship usually serves either to confirm the validity of a legal theory empirically or to fine-tune policymaking in a particular domain. ${ }^{25}$ If methods are reflected on at all, they tend to be assessed instrumentally in terms of their "usefulness ... to the practising lawyer ... as opposed to the academic analyst" and thereby reduced to an inert vocational service-delivery role. ${ }^{26}$

Johns' article avoids these methodological pitfalls by adopting a descriptive, rather than normative, approach to international law. Drawing from Foucauldian-inspired genealogies of Anne Orford and the ethnographic studies of Annelise Riles, Johns' theoretical interventions are embedded in her description of how international authority works and generated from mundane technical materials. ${ }^{27}$ The aim is to make visible that which is already in plain sight yet unseen, and Johns succeeds here in using description to reveal insights into how international law is changing through automation. ${ }^{28}$

The international legal regime on nuclear nonproliferation enacted by the 1968 Treaty on the Non-Proliferation of Nuclear Weapons (NPT), for example, privileges a particular form of observation by IAEA inspectors and empowers a class of "specially anointed" experts to act as the world's "official sensors." " But with the increasing collection and analysis of satellite imagery and other geospatial data by the IAEA, unstructured data mining techniques are now commonly used to identify "patterns" of potential interest without the need for any human in the loop. Building on this description, Johns observes that "even the determination of what constitutes an 'object' for purposes of analysis and change detection is automated." 30 In other words, the ocular inspection regime, elite observation practices and professional class of detection experts envisaged by the international nonproliferation legal regime are being quietly supplanted by data mining and machine learning techniques. Johns highlights the contradictions between international law's normative promise and practice merely by describing its technicalities.

${ }^{23}$ Johns, supra note 3, at 67, 68 .

${ }^{24}$ Martti Koskenniemi, Letter to the Editors of the Symposium, 93 AJIL 351, 354 (1999).

${ }^{25}$ Gregory Shaffer \& Tom Ginsburg, The Empirical Turn in International Legal Scholarship, 106 AJIL 1 (2012).

${ }^{26}$ Stephen R. Ratner \& Anne-Marie Slaughter, Appraising the Methods of International Law: a Prospectus for Readers, 93 AJIL 291, 299 (1999); Ingo Venzke, International Law and its Methodology: Introducing a New Leiden Journal of International Law Series, 28 LEIDEN J. INT'L L. 185,186 (2015).

27 Anne Orford, International Authority and the Responsibility to Protect (2011); Anne Orford, In Praise of Description, 25 LEIDEN J. INT'L L. 609 (2012); RILES, supra note 7.

${ }^{28}$ Orford, supra note 27, at 617; Riles, supra note 7, at 229.

${ }^{29}$ Johns, supra note 3 , at 72,73 .

${ }^{30} \mathrm{Id}$. at 88. 
It's a powerful move and form of critique that seeks to reinvigorate the politics of international law "by describing problems and constraints anew" and "attending to what is hidden, disavowed, or implicit" within them. ${ }^{31}$

Another innovative aspect of Johns' method lies in her attention to the agency of things and what she calls "international legal infrastructure." 32 The nonhuman objects that feature in this text-such as the UNHCR field guides, biometric databases, nuclear nonproliferation protocols, satellites, data mining processes and citizen sensors-are not inert tools, quietly placed in the background of international law. They are active protagonists in the global legal changes that Johns is describing, enabling and conditioning international law. Here Johns draws on what ANT theorists call the principles of "generalised symmetry"- where anything that produces effects within a given network is deemed to be an actor and afforded agency, irrespective of its ontological status. ${ }^{33}$ It is a bold move that is not often tried in international legal scholarship. The burgeoning literature on indicators-which emphasizes how governance technologies help produce the very categories they purport to describe-is as close as it gets. ${ }^{34}$ Yet Johns is at pains to distinguish her work from this quantification literature, instead situating it within a "new wave" of sociolegal scholarship on Big Data analytics. ${ }^{35}$

Whilst I am excited by the possibilities of this new wave emerging, I am not persuaded that the existing literature on governance technologies and quantification practices has no role in the brave new world of automation. ${ }^{36} \overline{\text { Algorithms }}$ may detect unknown patterns in distinct and opaque ways, but they usually do so within sociotechnical assemblages where shared practices of verification and measurement remain important elements in data analysis. ${ }^{37}$ In my own area of research on security lists and databases, for example, conventional watchlisting techniques (to find "known" terrorists) and novel algorithmic processes (to identify "unknown" terrorists) are often used together. ${ }^{38}$ Techniques of quantification and correlation, in other words, are both important in the governance of terrorism.

There is also a tension in Johns' text between Big Data as an epochal break in international authority that stands to usher in a new era of automated decisionmaking and Big Data as a technological development that reconfigures and extends existing governance practices. This mirrors broader social debates about the relative novelty of the Big Data "revolution." For some, Big Data is a "game changer" that enables "an entirely new epistemological approach for making sense of the world." 39 For others, such novelty claims are overstated and work to "limit the potential of critical engagement." ${ }^{40}$ Johns oscillates between these positions throughout the text. This is not so much a problem as a productive friction that animates the article. It works to strengthen, rather than detract from, Johns' core claim that we need to "engage politically with the technical terms and practices through which resources and authority are distributed on the global plane" as a matter of urgency. ${ }^{41}$

${ }^{31}$ Wendy Brown \& Janet Halley, Introduction, in Left Legalism/Left Critique 33 (Wendy Brown \& Janet Halley eds., 2002), cited in Fleur Johns, On Writing Dangerously, 26 Sydney L. Rev. 473, 479 (2004); Mariana Valverde, “Non-Legality” and Society, 27 LEIDEN J. INT'L L. 961, 964 (2014).

32 Johns, supra note 3, at 82; Emily Grabham, Breining Legal Times: Things, Forms and the Enactment of Law (2016).

${ }^{33}$ Bruno Latour, The Making of Law: An Ethnography of the Conseil D’État (2010); John Law, Notes on the Theory of the ActorNetwork: Ordering, Strategy, and Heterogeneity, 5 Sys. PRAc. 379 (1992).

34 Governance by Indicators: Global Power Through Classification and Rankings (Kevin E. Davis et al. eds., 2012).

35 Johns, supra note 3 , at 65, 66 .

36 See, e.g., Evelyn Ruppert, The Governmental Topologies of Database Devices, 29 Theory, Culture \& Soc'y. 116 (2012); Algorithmic Life: Calculative Devices in the Age of Big Data (Louise Amoore \& Volha Piotukh eds., 2016).

${ }^{37}$ Mareile Kaufmann \& Julien Jeandesboz, Politics and "the Digital": from Singularity to Specificity, Eur. J. Soc. ThEORY 1 (2016).

38 Marieke de Goede \& Gavin Sullivan, The Politics of Security Lists, 34 Env'T \& PLAN. D: Soc'y \& SpaCE 67 (2016); Johns, supra note 12.

39 Rob Kitchin, Big Data, New Epistemologies and Paradigm Shifts, 1 Big Data \& Soc’y 1 (2014).

${ }^{40}$ Claudia Aradau \& Tobias Blanke, The (Big) Data-Security Assemblage: Knowledge and Critique, 2 Big DATA \& Soc’y 1 (2015).

41 Johns, supra note 3 , at 103. 
There is a growing recognition that the international legal landscape is in motion. As some have put it: "The conceptual boundaries of how international law may look in the future are wide open." ${ }^{42}$ And whilst sociolegal scholarship has long been tethered to the state and preoccupied with domestic concerns, it is increasingly scaling up to analyze "global sites of legal production" and the emergent domains of "uncharted law" that mark the postnational present. ${ }^{43}$ There are good reasons for bringing these once-divergent traditions of legal scholarship into closer relation. By taking on the technicalities of contemporary global governance, Johns' text is an important and valuable movement in that direction.

42 Joost Pauwelyn et al., When Structures Become Shackles: Stagnation and Dynamics in International Lawmaking, 25(3) Eur. J. INT'L L. 733 , 734 (2014).

${ }^{43}$ Sally Engle Merry, New Legal Realism and the Ethnography of Transnational Law, 31 Law \& Soc. InQuiRy 975, 980 (2006); Neil Walker, Out of Place and Out of Time: Law's Fading Co-Ordinates, 14 Edinburgh L. Rev. 13 (2010). 